\title{
EVALUATION OF FUNGICIDES FOR CONTROL OF DOWNY MILDEW OF LETTUCE
}

\author{
P.J. WRIGHT \\ Crop \& Food Research, Cronin Road, RD1, Pukekohe, New Zealand \\ Corresponding author:wrightp@crop.cri.nz
}

\begin{abstract}
Downy mildew (Bremia lactucae) is an economically important disease of lettuce in New Zealand. At present, few chemicals are registered in this country for control of this disease. The aim of this experiment was to evaluate the efficacy of 10 chemicals for control of downy mildew of lettuce. The experiment was laid out in a randomised block design with four replicates. An Oxford precision sprayer, calibrated to 500 litres/ha, was used to apply the chemicals. Disease assessments were carried out weekly. On 25 October 2006, 20 plants in the center two rows of each plot were harvested and assessed for downy mildew. Non-sprayed plants had $24.5 \%$ basal area infected. All ten fungicides tested reduced downy mildew. Fosetyl-aluminium had significantly $(\mathrm{P}<0.05)$ lower levels of downy mildew (2.0\% basal area affected) than the other fungicides. Metalaxyl plus mancozeb and azoxystrobin gave good control of downy mildew (with 2.8\% and 3.9\% basal area affected respectively). Copper hydroxide and mancozeb gave poorest control of the disease (7.4\% and 6.8\% basal area affected respectively). Based on the results of this experiment, fosetyl-aluminium, metalaxyl plus mancozeb, and azoxystrobin show promise for control of lettuce downy mildew in New Zealand.
\end{abstract}

\section{IDENTIFICATION, PATHOGENICITY AND COLD TOLERANCE OF STRAWBERRY LEAK ISOLATES IN NEW ZEALAND}

\author{
N.W. WAIPARA ${ }^{1}$, B. MASSEY ${ }^{1}$, O.E. TIMUDO-TORREVILLA ${ }^{2}$, \\ K.S.H. BOYD-WILSON ${ }^{3}$, G.I. LANGFORD ${ }^{3}$, L.G. HAWES ${ }^{4}$ \\ and M. WALTER ${ }^{3}$
${ }^{1}$ Landcare Research, 231 Morrin Road, P Bag 92170 Auckland, New Zealand
${ }^{2}$ HortResearch, Private Bag 92169, Auckland, New Zealand
${ }^{3}$ HortResearch, PO Box 51, Lincoln, New Zealand
${ }^{4}$ Enderley Investments Ltd, 78 Enderley Ave, Hamilton, New Zealand \\ Corresponding author: WaiparaN@landcareresearch.co.nz
}

Commercially grown strawberries are susceptible to a range of pre and post-harvest rots including fruit leak, the second most prevalent economic fruit rot encountered in New Zealand. A survey was conducted over two growing seasons to identify the causal disease agents associated with leak symptoms. Micro-organisms were isolated from infected berries collected from commercial gardens in three growing regions, Auckland, Waikato and Canterbury. Isolates consisting of yeasts and Zygomycetes were identified using morphological and molecular diagnostic methods. Representative isolates were reinoculated onto berries to confirm pathogenicity (Koch's postulates). The majority of leak symptoms were associated with Rhizopus stolonifer, although Rhizomucor variabilis and Mucor piriformis were also identified. Post-harvest management of leak includes refrigeration, but some isolates of Rhizopus and Mucor were shown to be cold tolerant and could actively grow and reproduce at low temperatures $\left(4-6^{\circ} \mathrm{C}\right)$. This information will now be used to improve management and storage systems for post-harvest fruit. 